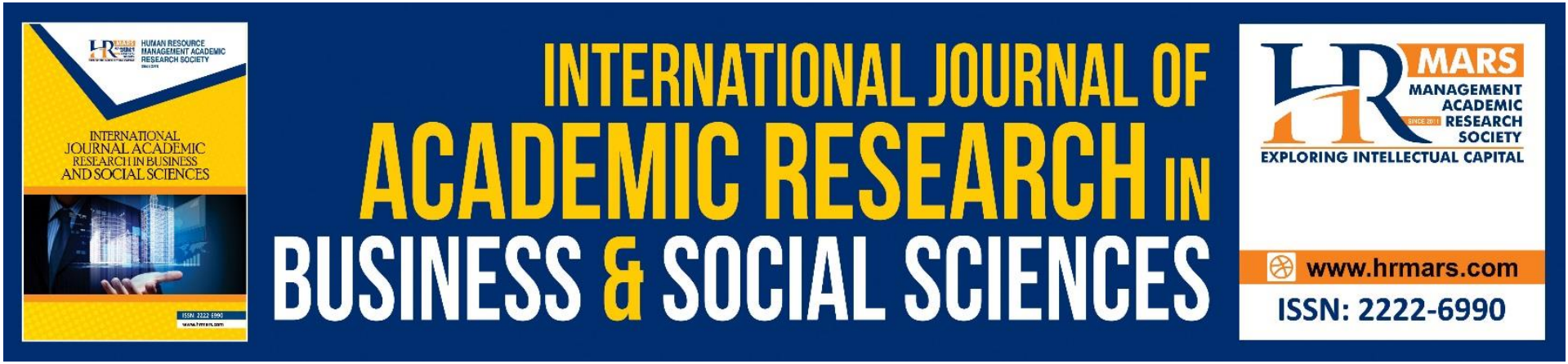

\title{
Mapping Environmental Citizenship in Higher Education
}

\section{Seyedali Ahrari, Siti Suria Salim, Nor Wahiza Abdul Wahat}

To Link this Article: http://dx.doi.org/10.6007/IJARBSS/v11-i11/11300

DOI:10.6007/IJARBSS/v11-i11/11300

Received: 13 September 2021, Revised: 16 October 2021, Accepted: 29 October 2021

Published Online: 09 November 2021

In-Text Citation: (Ahrari et al., 2021)

To Cite this Article: Ahrari, S., Salim, S. S., \& Wahat, N. W. A. (2021). Mapping Environmental Citizenship in Higher Education. International Journal of Academic Research in Business and Social Sciences, 11(11), 1154 -1160 .

Copyright: (C) 2021 The Author(s)

Published by Human Resource Management Academic Research Society (www.hrmars.com) This article is published under the Creative Commons Attribution (CC BY 4.0) license. Anyone may reproduce, distribute, translate and create derivative works of this article (for both commercial and non-commercial purposes), subject to full attribution to the original publication and authors. The full terms of this license may be seen at: http://creativecommons.org/licences/by/4.0/legalcode

Vol. 11, No. 11, 2021, Pg. $1154-1160$

Full Terms \& Conditions of access and use can be found at http://hrmars.com/index.php/pages/detail/publication-ethics 


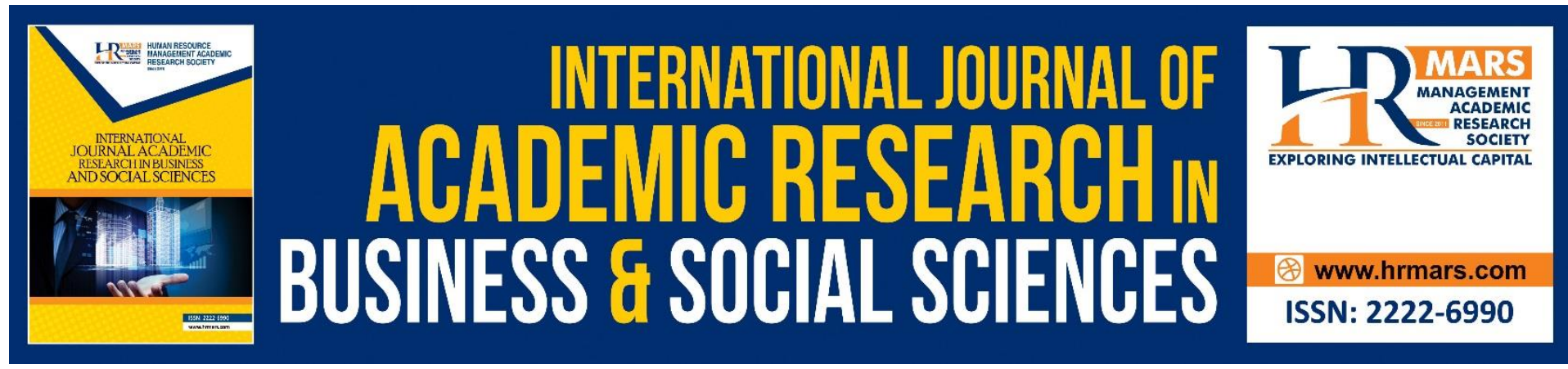

\title{
Mapping Environmental Citizenship in Higher Education
}

\author{
Seyedali Ahrari, Siti Suria Salim, Nor Wahiza Abdul Wahat \\ Faculty of Educational Studies, Universiti Putra Malaysia, Serdang, 43400, Selangor, \\ Malaysia \\ Corresponding Author Email: ssuria@upm.edu.my
}

\begin{abstract}
Environmental citizenship can be obtained as a requirement to enhance pro-environmental behavior among university students. It takes a bottom-up tactic by including the shared views of all actors - students, ENGOs, university leaders, and governments - in an attempt to achieve lasting environmental outcomes. Before there were no models for higher education based on environmental citizenship and this paper, thus, is trying to fill this gap and suggest some issues necessary for achieving environmental citizenship. The model is derived and it explored the inter-linkages on how to involve the students in pro-environmental activities through the features of environmental citizenship that can affect the environmental outcome. Based on the model, one of the tasks of universities is to improve their strategy and curricula towards more participatory actions and decision-making concerning the environment and to act accordingly.
\end{abstract}

Keywords: Environmental Citizenship, Higher Education, Environmental Problem, ProEnvironmental Behaviour, Environmental Education

\section{Introduction}

Over the past years, there have been great anxieties over the environmental problems and the changing lifestyles in making them more serious. These problems (e.g., Global warming, pollutions) have been obvious since they have been confirmed to be blamable for thirty million deaths yearly (WHO, 2009). Education is the main motive for explaining these environmental anxieties. In this sense, the level of environmental information in addressing lifestyles and attitudes could be critical in altering persons' behavior (Adomssent, 2013). Though, being literate does not certainly form students' pro-environmental behaviors, or able them to take action because the education system just teaches "about" the environment rather than how to make responsible environmental citizens. As a result, the solutions are considered as requiring the contribution of individual citizens for its change, alongside the attempts made by governments. Since the 1990s, environmental citizenship has found itself as a unique way of linking concerns, the public, and policy. Currently, many universities have shown interest by offering to fund more research and have also been involved in organizing many programs and extracurricular activities to raise environmental awareness and student involvement (HOLCIM, 2006). Also, there are some increasing campaigns and volunteer works 
(e.g., Tree planting) for instance special mango groves to promote environmental participation, such as Universiti Putra Malaysia (UPM, Juferi, 2014). But there are no firm environmental citizenship models towards pro-environmental behavior for universities to push students to take active roles as environmental citizens (Ahmad et al., 2012). This paper, therefore, attempts to put forward a model of civic environmentalism in universities' context because it can address characteristics of being a civilized student including environmental information, awareness, concern, and personality.

\section{Environmental Citizenship Model}

Environmental citizenship has the responsibility to learn about the environment, to take responsible action, and to encourage thinking about the duties, rights, and engagement in restoring the Earth. It is rooted in traditions of republican, liberal, and cosmopolitan types of citizenship (Dobson, 2003). The previous models in the traditions of Republicans were more based on a top-down style that avoids students' participation (Agyeman \& Evans, 2006). But in the stages of the liberal and cosmopolitan type of citizenship, it reflects the changing expectations of the public and environmental agencies through bottom-up style. This is based on the varying from civic involvement to more formal actions. This involvement focus has grown out of a more diverse activist who can address the connections between environmental problems and citizenship education as well as draw on the notion of rights, ethics, and reducing the ecological footprint. In this regard, most environmental citizenship models are framed with the following features:

1. Information: about environmental problems, causes, and consequences.

2. Awareness: aware of the dangerous consequences and responsible for altering the environmental disorders.

3. Concern: the emotional response to his/her understanding of damages.

4. Personality: i.e. Attitude to the new environmental ideas, locus of control, sense of social-personal responsibility, economic preference, emotionality, religious attachment, and environmentally responsible behavior.

These features can able students to improve environmental conditions of commitment and engagement as citizens. This also is true in the educational reform by moving from a narrow view to a broader one. However, there are many challenges that for the sort of curriculum reform, we are discussing, a "bottom-up" approach.

\section{Challenges and Issues of Environmental Citizenship}

Nowadays, we are living in an "environmental emergency" because we do not know what it means to be an environmental citizen. It is the second generation of environmentalism, which is known as the "third way" and a "bottom-up" approach to environmental policy. However, practicing this has some challenges and issues which may be lead to some environmental ambiguity (Zaremohzzabieh et al., 2021). In the first challenge, when environmental problems such as climate change have come to the front, citizens are gradually seen as the responsible causes when refraining from acting on climate-chic behaviors, (e.g., Reusing, turning the thermostat down, using public transport, etc.). In Malaysia, civic involvement in environmental problems is recognized as a key to sustainability, but, they don't know why they should be responsible for improvements that would not directly benefit them (Ahmad et al., 2012). However, even responsible citizens still fail to act on their concerns. In the second challenge, despite some awareness of environmental problems such as the crisis over fossil fuels, evidence that this is causing key modifications in behavior (e.g., Energy use) is not 
convincing and there is little sign of a commitment to the collective values assigned to environmental citizenship (Flynn et al., 2008). Also, there is a dispute between citizens' awareness and their motivation for pro-environmental behavior. This issue was uttered as a social dilemma that concerns the tension between citizens' self-interest and communal welfares. An example of this dilemma is whether citizens choose to recycle or not. To act under private interests will, in this situation is to not recycle, since it incorporates additional expense to the individual as far as sorting out the waste. The collective choice, in this case to recycle everyday waste, infers that an individual accepts some expense so as to avoid lasting negative results. The original cause of the depletion of natural resources in a large-scale social dilemma is the unlimited access to natural resources - either renewable or nonrenewable that people have. In addition, another issue is that when they decide whether to collaborate or not, social interdependency is not always salient. To act in unity with the collective demands (at least some) information about the interdependency on the situation is called for. The stronger the self-centered motivation, which "is concerned with the removal of suffering and harm from oneself", for action, the more likely this action is to be performed (Kollmuss \& Agyeman, 2002). The last challenge is the awareness of citizens to their patterns of lifestyles are limited by social structures which they usually regard as beyond their direct control. A higher material standard of living means producing more goods-cars, houses, dryers, water heaters, and air conditioning systems, and so on, resulting in further environmental pollution. Hence, there is a need to address the above issues and challenges related to proenvironmental behavior of citizens in the context of higher education.

\section{Environmental Citizenship Model in the Context of Higher Education}

Achieving environmental citizenship would remain an aspirational concept without the inclusion of all segments in a participatory way. Particularly, university students need to play a key role in this process, because they are an important part of all characteristics of environmental citizenship in the context of higher education. No advances in developing a culture of civic environmentalism will occur without involving the students in that context. In this model, it prescribes on the value of paying attention to features of environmental citizenship in the higher education context in four elements:

(1) Environmental information can help them to have more responsibility towards the environment and behave in ways that contribute to the environmental solutions;

(2) Environmental awareness can motivate students to be responsible for changing the offensive environmental conditions;

(3) Environmental concern refers to the students' beliefs and to which they support efforts to solve them and indicate a willingness to contribute personally to their solution (i.e. Concern about waste, health, and energy awareness to environmental technology); and

(4) Personality is the type of students, which is shown by the way of their behavior, feeling, and thinking and it can affect environmental concern and pro-environmental behavior.

Indeed, it cannot be denied that positive forces in universities are the foundations of these characteristics (see in figure 1). In terms of principles as a first positive force, the role of education in changing lifestyles and environmental awareness could be crucial in altering students' behavior and in turning society towards environmental sustainability. Besides Dobson and Bell (2006) argue that part of education's role in our world is to promote environmental citizenship, something which requires greater promises from higher education institutions. In the sense of practice as the second level, objectives of higher education programs must be explicit, and socio-cultural and environmental information should be 
expressed in courses. In doing so, a different curriculum from the majority of today's environmental programs can provide students with information and a set of skills to interact as environmental citizens to solve environmental issues, and to combine technical thought into the assessment of problems and the advance of solutions and its content requires a foundation in pragmatic work which it means that content and outcomes are programed by experts. In the third level, students are allowed to build their ideas (Hodson, 2003) to scrutinize lifestyles critically to understand the sources of environmental problems and find solutions at both the individual and societal level (Ahrari et al., 2013; Jensen \& Schnack, 1997; Muhammad et al., 2018) which make possible moving into action. Hence, the connection can be made between the need for these environmental civic characteristics for environmental protection (e.g., Public health, disaster management) by active involvement in the attainment of sustainable communities (Agyeman \& Angus, 2003) because bottom-up civic environmentalism is a process of local problem solving and decision making, and communitybased environmental protection. Finally, higher education can serve as a model of sustainability and help economic development with a more sustainable environment, and therefore community building is achievable.

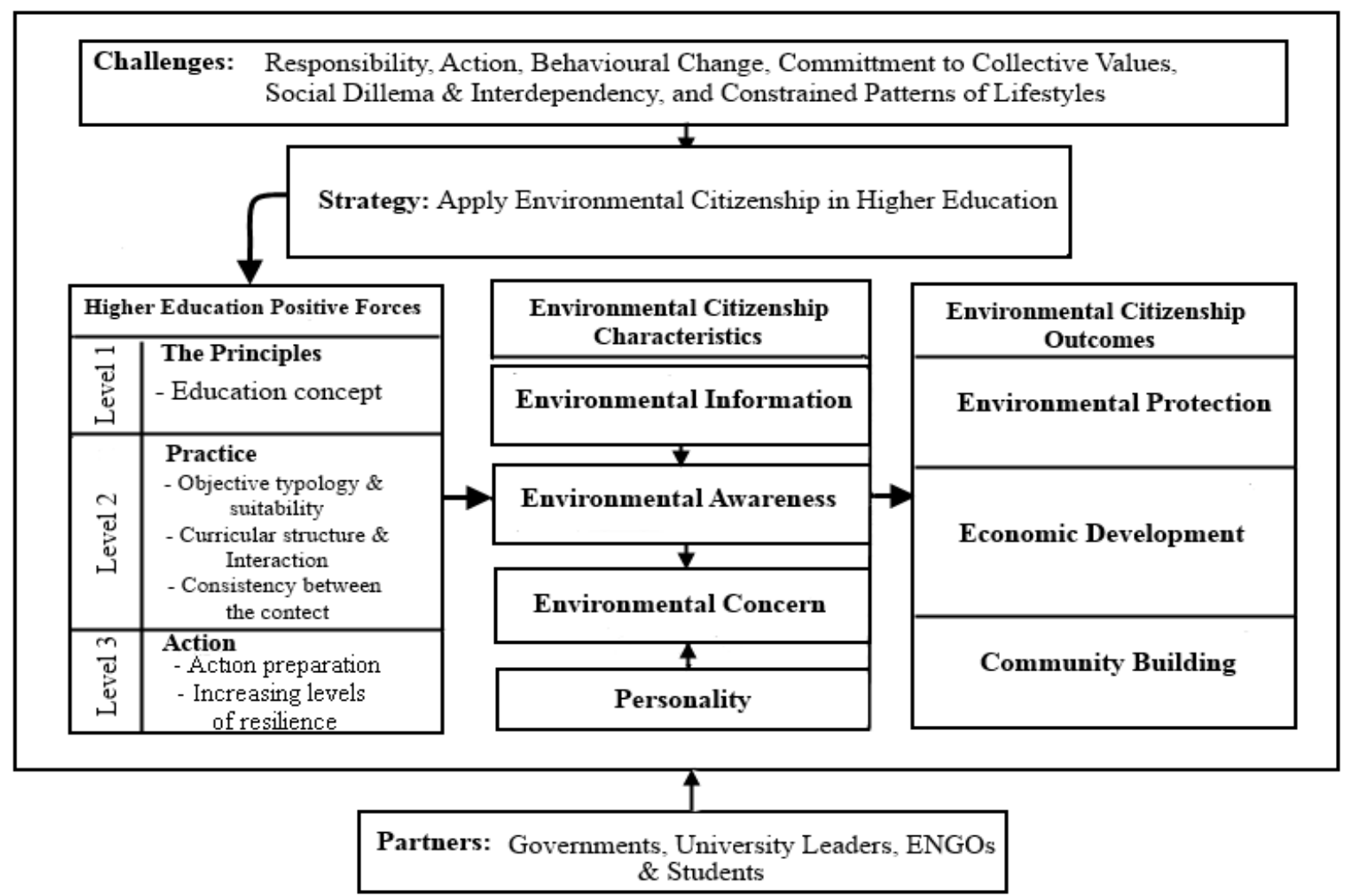

Figure1. A proposed framework for environmental citizenship

\section{Conclusion}

This study develops a model to capture the factors that influence environmental outcomes in higher education. At this point, it was identified that students need to play a key role in achieving solutions for environmental problems as environmental citizens because they are a vital part of all characteristics of environmental citizenship. Environmental citizenship has been defined as a simple repetition of a known fact - that the protection of the environment is a duty trusted upon the student as citizens and all stakeholders by the inherent relationship between citizens and nature and between citizens and governments. 


\section{Implications}

Environmental citizenship education cultivates a coherent and adequate body of knowledge, as well as the necessary skills, values, attitudes, and competencies for an environmental citizen to act and participate in society as an agent of change in the private and public spheres, on a local, national, and global scale, through individual and collective actions. It encourages higher education to focus on fixing current environmental issues, avoiding the emergence of new ones, attaining sustainability, and cultivating a healthy relationship with nature.

Lecturers and students should also promote Environmental Citizenship and engage more effectively with various sectors of society to convert society into a more sustainable one. Civil society must engage in open dialogue with the government to push policymakers to make the right decisions and move beyond calls to action. Environmental citizenship education should provide citizens with the skills they'll need to succeed. Environmental Citizens must consequently possess political and communication skills, as well as environmental and sustainability-related information, attitudes, and values, to urge people to take action.

Environmental citizenship education implies that these students are at the heart of the responsibility of the solution. This model explores the inter-linkages on how to encourage students to take action and how to involve in the community. There are four main characteristics of environmental citizenship that affect the students. Based on these characteristics, it is crucial to handle the challenges of being an environmental citizen. Universities should use their positive forces and target the future role of students as citizens. Civic environmentalism was rooted in developed countries, but they are employing it in their universities for a more sustainable socio-economic development. The study has some recommendations for increasing environmental citizenship in higher education institutions: 1-Environmental citizenship should be a key issue when dealing with curriculum reform.

2-Universities should shift from contents to competencies by novel teaching approaches.

3-Invest more in facilities for teaching and employ the best experts in the field.

4-Emphasize on extracurricular activities for environmental awareness.

\section{References}

Adomssent, M. (2013). Exploring universities' transformative potential for sustainabilitybound learning in changing landscapes of knowledge communication. Journal of Cleaner Production, 49, 11-24.

Agyeman, J., \& Angus, B. (2003). The Role of Civic Environmentalism in the Pursuit of Sustainable Communities. Journal of Environmental Planning and Management, 46(3), 345-363. https://doi.org/10.1080/0964056032000096901

Agyeman, J., \& Evans, B. (2006). Justice, governance, and sustainability: Perspectives on environmental citizenship from North America and Europe. In A. Dobson \& D. Bell (Eds.), Environmental Citizenship. MIT Press.

Ahmad, A. L., Rahim, S. A., Pawanteh, L., \& Ahmad, F. (2012). The Understanding of Environmental Citizenship among Malaysian Youths: A Study on Perception and Participation. Asian Social Science, 8(5), 85-92. https://doi.org/10.5539/ass.v8n5p85

Ahrari, S., Othman, J., \& Hassan, M. (2013). Role of Social Studies for Pre-Service Teachers in Citizenship Education. International Education Studies, 6(12), 1-8. https://doi.org/10.5539/ies.v6n12p1

Dobson, A. (2003). Citizenship and the Environment. Oxford University Press.

Dobson, A., \& Bell, D. (Eds.). (2006). Environmental Citizenship. The MIT Press Cambridge. 
Flynn, R., Bellaby, P., \& Ricci, M. (2008). Environmental citizenship and public attitudes to hydrogen energy technologies. Environmental Politics, 17(5), 766-783. https://doi.org/10.1080/09644010802421539

Hodson, D. (2003). Time for action: Science education for an alternative future. International Journal of Science Education, 25(6), 645-670.

Holcim Foundation for Sustainable Construction (HOLCIM). (2006). http://www.holcim.com.my

Jensen, B. B., \& Schnack, K. (1997). The action competence approach in environmental education. Environmental Education Research, 3(2), 163-178.

Juferi, N. E. (2014). Special Mango Grove to Promote Environmental Conservation. http://www.upm.edu.my/berita/details/dusunmanggabi?LANG=en

Kollmuss, A., \& Agyeman, J. (2002). Mind the gap: Why do people act environmentally and what are the barriers to pro-environmental behavior? Environmental Education Research, 8(3), 239-260.

Muhammad, M., Krauss, S. E., Zaremohzzabieh, Z., Meng, L. K., Hamzah, A., Samah, B. A., \& Tamam, E. (2018). Adaptation and Psychometric Evaluation of a Core Competencies Measure for Malaysian Youth Workers. Young, 26(4), 383-405.

WHO. (2009). Preventing disease through healthy environments: Towards an estimate of the environmental burden of disease. http://www.who.int/ quantifying_ehimpacts/publications/preventingdisease/en/index.html

Zaremohzzabieh, Z., Ismail, N., Ahrari, S., \& Samah, A. A. (2021). The effects of consumer attitude on green purchase intention: A meta-analytic path analysis. Journal of Business Research, 132, 732-743. https://doi.org/10.1016/j.jbusres.2020.10.053 